\title{
100 years of sickle cell disease research: etiology, pathophysiology and rational drug design (part 1)
}

\author{
Mona A. Mahran* ${ }^{*}$, Mohamed Teleb Ismail and Elwy H. Abdelkader
}

\begin{abstract}
Background: Sickle cell disease (SCD) is a chronic hemolytic disease caused by an altered hemoglobin molecule $(\mathrm{HbS})$ and was first termed as a molecular disease. Glutamic acid in the normal hemoglobin molecule (HbA), was replaced by valine in $\mathrm{HbS}$ at the sixth position of both $\beta$-chains. This alteration was proved to be due to a single point mutation GTG instead of GAG in the genetic code. Since the discovery of sickle cell disease in 1910, great efforts have been done to study this disease on a molecular level. These efforts aimed to identify the disease etiology, pathophysiology, and finally to discover efficient treatment. Despite the tremendous work of many research groups all over the world, the only approved drug up to this moment, for the treatment of SCD is the hydroxyurea.
\end{abstract}

Main text: In this review, the antisickling pharmaco-therapeutics will be classified into two major groups: hemoglobin site directed modifiers and ex-hemoglobin effectors. The first class will be discussed in details, here in, focusing on the most important figures in the way of the rational drug design for SCD treatment aiming to help scientists solve the mystery of this problem and to get clear vision toward possible required therapy for SCD.

Conclusion: Despite the large number of the antisickling candidates that have been reached clinical studies yet, none of them has been introduced to the market. This may be due to the fact that hemoglobin is a large molecule with different target sites, which requires highly potent therapeutic agent. With this potency, these drugs should be safe, with acceptable oral pharmacokinetic and pharmacodynamic properties. Such ideal drug candidate needs more efforts to be developed.

Keywords: Sickle cell disease, Antisickling pharmaco-therapeutics, Alloesteric effectors, Vanillin

\section{Background}

Sickle cell anemia was first discovered by J. B. Herrick in 1910 [30], who noted morphological difference between normal RBC's (disc shape) and abnormal (elongated shape) of the sickled RBC's. In 1923, the reversibility of RBC's sickling was reported [65], whereas the correlation between oxygen tension and sickling was declared, many years later, by Hahn and Gillespie [27]. They stated that sickling occurs only under low oxygen tension, while erythrocytes regain its normal shape by increasing oxygen partial pressure. The breakthrough information of the sickle cell disease (SCD) was the discovery by

\footnotetext{
* Correspondence: mahranmona@yahoo.com

Department of Pharmaceutical Chemistry Faculty of Pharmacy, Alexandria University, El-Khartom square, El-Azarita, Alexandria 21521, Egypt
}

Pauling et al. in 1949 [55] that SCD was caused by an altered hemoglobin molecule $\mathrm{HbS}$ and was first termed a molecular disease. The same research group also proposed a mechanism of the sickling phenomenon which happens due to the interaction of the complementary deoxy $\mathrm{HbS}$ molecules to form long chains that attract one another forming a crystal or liquid crystal. This postulation was supported by Harris' observation that $10 \%$ of the deoxy HbS solution consists of a polymer [29]. Using peptide mapping technique in 1956, Ingram reported that glutamic acid in the normal hemoglobin molecule $(\mathrm{HbA})$ was replaced by valine in $\mathrm{HbS}$ at the sixth position of both $\beta$-chains [33, 34]. In 1977, Marotta research group proved that the replacement of glutamic acid by valine is due to a single point mutation GTG instead of GAG in the genetic code [42]. Indeed, electron 
microscopy and X-ray diffraction analysis described the structure of $\mathrm{HbS}$ fiber as a 14-stranded fiber, each strand is formed of seven proto-filaments $[17,18]$. Under low oxygen conditions, the mutant hemoglobin ( $\mathrm{HbS})$ polymerizes through intermolecular contact between the mutated $\beta$ Val6 from one $\mathrm{Hb}$ tetramer and a hydrophobic pocket formed by $\beta 1$ Ala70, $\beta 1 \mathrm{Phe} 85$, and $\beta 1 \mathrm{Leu} 88$ residues on a different tetramer. The formation of these polymers results in losing the normal disc shape of RBCs with the formation of sickle-like shaped RBCs, where they become more fragile. These sickle cells are unable to pass through narrow capillaries resulting in painful vaso-occlusive crises [57]. As a result, the sickle cells undergo hemolysis leading to anemia and a shortened lifespan. The vaso-occlusive crises is associated with fever, severe pain in the extremities, chest, back, and/or abdomen. Moreover, aplastic hematologic crisis due to viral or bacterial infection, or hemolytic crisis due to infection or other etiologic reasons were reported [32]. Aplastic hematologic crisis causes injury of the bone marrow cells which in turn decreases the erythrocytes production. On the other hand, hemolytic crisis leads to destruction of the circulating erythrocytes which causes a decrease in the hematocrit values. Transfusions are lifesaving for patients in this stage of the disease. Hydroxyurea [14], a myelosuppressive agent, is the only effective drug proven to reduce the frequency of painful episodes.

\section{Main text}

\subsection{Introduction}

Apparently, there is a leap in the recent research for potential treatment of SCD. This was evident by the large number of published research articles in many international journals and conferences along with several drug candidates in phase I, II, and III clinical trials $[6,13$, $15,41,66]$. This progress, in our opinion, is provoked by the discovery of many ex-hemoglobin sites which have been reported as targets to control sickling or gelling of $\mathrm{HbS}$. A prime example of such sites is RBC's cell membranecalcium-activated potassium channel (Gardos channel); one of the main routes for $\mathrm{K}^{+}$loss and dehydration in RBCs $[24,26,35]$, which could be blocked by clotrimazole and other imidazole inhibitors [10]. Additionally, DNA methyl transferases [63] and histone deacetylase [31] are viewed as validated antisickling targets that could be inhibited for inducing fetal hemoglobin $(\mathrm{HbF})$ that does not participate in the polymerization of hemoglobin subsequently decreases HbS polymerization [21, 45]. Similarly, inhibition of the rho kinase protein [40] by hydroxyfasudil shows promise in SCD treatment as it increases endothelial NO synthase levels and induces $\mathrm{HbF}$ [21]. Another approach is targeting adenosine signaling that is responsible for multiple pathophysiological roles in SCD through subtype $2 \mathrm{~B}$ adenosine receptors antagonism [22]. Such discoveries opened the gate for scientists to explore new approaches and to rationally design new small molecules as potential antisickling agents $[16,21]$. Thirty years ago, site-directed modification of hemoglobin was the major strategy used to design antisickling candidates targeting different hemoglobin pockets that were identified using X-ray diffraction analysis. Those hemoglobin effectors were classified according to their mode of interaction with hemoglobin into covalent and non-covalent-binding hemoglobin alloesteric effectors. Covalent modifiers are molecules that bind covalently to one or more reactive sites of hemoglobin. Examples of the covalent binding effectors are cyanates $[11,43,49]$, aldehydes [4, 48], acetyl salicylates [67, 68], $\alpha, \beta$-unsaturated carbonyls [38, 54], and nitrogenmustard derivatives $[23,58]$. On the other hand, noncovalent modifiers (e.g., aromatic amino acids [25, 59], ureas [12], alkonic acids [20,53], and esters [9]) bind to $\mathrm{Hb}$ through ionic, Van der Waal, or hydrogen bond force of interaction that leads to polymer destabilization (antigelling) or breaking the salt bridges which results in shifting the allosteric equilibrium and the subsequent increases in $\mathrm{HbS}$ affinity for oxygen (antisickling).

Antisickling pharmaco-therapeutics could be generally classified into two major groups: hemoglobin site-directed modifiers and ex-hemoglobin effectors. In this part, only the first class will be discussed in more details, in order to gather all ideas, strategies, and outcomes of the research and efforts made for discover new treatment of SCD, whereas the second class is stated herein in brief and will be discussed in details in part II review.

\subsection{Hemoglobin allosteric modifiers}

Hemoglobin allosteric modifiers (HAM) include any natural or synthetic therapeutic agent that targets hemoglobin to change its properties with the aim to inhibit its sickling and/or its polymerization to be useful for the treatment of SCD. The first attempt to synthesize stereospecific HbS modifiers was published in 1977 [39]. This work was based on the hypothesis that $\mathrm{HbS}$ aggregation could be abolished by an oligopeptide that mimics the amino acid sequence of the mutation site at the donor area of the HbS tetramer. This oligopeptide would competitively inhibit binding with the acceptor site of the other $\mathrm{HbS}$ tetramer and presumably prevent polymerization. Different series of oligopeptide amides were synthesized e.g., $\beta 1-6, \beta 3-6, \beta 5-6$, and even longer sequences of the $\mathrm{N}$-terminal region of the $\mathrm{HbS}$ $\beta$-chains $(\beta$ 1-8) $[39,69]$. The obtained results indicated that oligopiptide sequence $\beta$ 1-6 possesses the highest activity as inhibitor of $\mathrm{HbS}$ aggregation. However, when changing the sequence order of such peptide as $\beta 125634$ $\mathrm{HbS}$, it maintained the same activity, which indicated lack of specify.

In 1984, an allosteric non-competitive DPG (2,3-diphosphoglycerate) antagonist, BW12C, was designed targeting 
the $\alpha$-amino terminal of oxy HbS [7]. DPG along with $\mathrm{H}^{+}$ are the natural allosteric effectors that lower $\mathrm{Hb}$ affinity for oxygen. BW12C's structure was designed to have an $o$ hydroxy group to the aldehyde moiety to stabilize the formed Schiff-base between one of the $\alpha \mathrm{N}$-terminal of the protein and the carbonyl of the aldehyde group. Indeed, the carboxylic group was included in the BW12C's structure to form salt bridge with the other $\alpha \mathrm{N}$-terminal of the oxy HbS. Despite of its antisickling activity in vitro and in vivo, BW12C has very short half-life (4 h).

In 1991, vanillin, a nutraceutical agent, was picked up as a safe antisickling lead compound [3], following the previous results reported by Zauggand and Beddel research groups $[8,70]$. Vanillin has a moderate antisickling effect and was proved to bind covalently with $\mathrm{HbS}$, increasing its oxygen affinity as well as decreasing RBC's sickling. However, due to its poor oral bioavailability, vanillin possessed weak antisickling effect after oral administration $[5,19,36,64]$. To overcome such drawback, a vanillin pro-drug was designed to have a thiazolidine protection of the aldehyde group to bypass the gastrointestinal metabolism. Such compound showed significant improved oral pharmacokinetics and pharmacodynamics, yet, it still suffered from some degradation in the digestive tract [71].
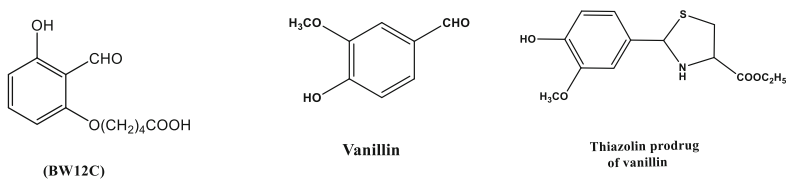

5-Hydroxymethyl-2-furfural (5-HMF, a vanillin isoster) was reported to have a remarkable antisickling activity. It is several times more potent than vanillin in inhibiting sickling and protecting sickle mice from hypoxia $[2,60]$. 5-HMF is currently in clinical trials in SCD patients [28].

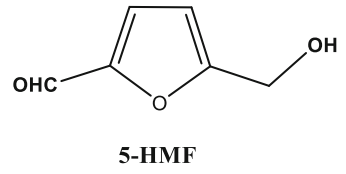

The structure activity relationship study of a series of 5HMFs as antisickling agents indicated that replacing the hydroxymethyl group at the 5-position of the furan ring as in 5-HMF by hydrophobic moieties (for example alkyl or alkoxy groups) decreases its activity, while its removal destroys the activity. This observation was confirmed by the crystallographic results implied the importance of the hydroxyl moiety of 5-HMF in the stabilization of the relaxed $\mathrm{R}$ state of hemoglobin [61]. Based on these results and using vanillin and pyridoxal (previously studied antisickling non-toxic aldehyde) [37] as scaffold, several pyridyl derivatives (INN) were developed and evaluated for their antisickling activity $[1,50,62]$. Amazingly, some of

these compounds showed as much as 90 and 2.5-foldpotency compared to vanillin and 5-HMF, respectively, although they bind at the same site of hemoglobin as 5HMF [1].

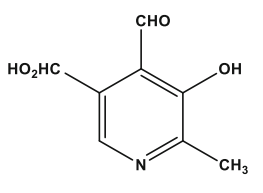

Pyridoxal<smiles>O=[N+]([O-])c1ccc(OCc2cccnc2)c(O)c1</smiles>

INN-312

In the same study, it was stated that the allosteric activity of these pyridyl derivatives is highly related to the position of the methoxy and pyridyl groups with respect to the aldehyde function. Generally, ortho-pyridyl benzaldehyde derivatives having a meta or para-methoxy substitution showed the highest activity, as in compound INN312, which act as a stereospecific inhibitor of the deoxy-HbS polymer while efficiently increasing the $\mathrm{Hb}$ affinity for oxygen [50].

In a trial to overcome the poor oral bioavailability of aldehydes, a series of imidazolylacryloyl derivatives were designed using ethacrynic acid (ECA); 2-(2,3-dichloro-4-(2methylenebutanoyl)phenoxy)acetic acid, as a pharmacophore [54]. ECA, a diuretic, was reported to inhibit $\mathrm{HbS}$ polymerization [38, 56]. However, its diuretic effect opposed its chance to be used in the treatment of SCD. The imidazolylacryloyl derivatives, referred as KAUS, have an $\alpha$, $\beta$-unsaturated ketone moiety, which was expected to undergo Michael addition on the thiol group of $\beta$ Cys93 in the same manner of ECA leading to the inhibition of sickling. Although those compounds did not show the expected activity, co-crystallization of deoxygenated or carbonmonoxy $\mathrm{Hb}$ with KAUS-12 or KAUS-1 showed an unexpected mode of Michael addition on the $\mathrm{N}$-terminal $\alpha \mathrm{Val} 1$ at the $\alpha$-cleft of the T-state structures of hemoglobin.<smiles>C=C(CC)C(=O)c1ccc(OCC(=O)O)c(Cl)c1Cl</smiles>

Recently, Metcalf's research team, using molecular modeling, has designed a new series of aldehydes having a bicylic ether link ortho to the aldehyde group. Their strategy was based on the ability of the aldehyde's carbonyl function group to form a Schiff base with the two Nterminal valines in both $\alpha$-chains in HbS, while the bicyclic moiety would fit more into the intradomain cavity [44]. This work was concluded successfully with the discovery of a new potent allosteric modifier of HbS, GBT440, having a pyrazol-5-yl-pyridine ether link. This compound was able to highly increase the hemoglobin affinity for oxygen 
which resulted in the decline of the polymerization of deoxy-HbS.<smiles>CC1c2cccnc2-c2ccnn2C1Oc1cccc(O)c1O</smiles>

\section{GBT440}

The X-ray analysis revealed that GBT440 [52] binds covalently to a single $\alpha$-chain in a 1:1 stoichiometry to the $\mathrm{HbS}$ tetramer. It is worth mentioning that all of the previously reported aldehydes bind covalently to the $\mathrm{HbS}$ chain in a 2:1 stoichiometry. It was reported that compound GBT440 possesses a high oral bioavailability in rats (60\%), with more than $19 \mathrm{~h}$ half-life. In addition, GBT440 partitions highly and preferentially into the red blood (RBC/ plasma ratio is $\sim 150$ ). Therefore, the authors proposed that GBT440 would be a superior antisickling hemoglobin modifier that specifically targets RBCs and exerts its effect in a relatively low therapeutic dose. Currently, GBT440 is in phase III clinical trials in SCD patients.

Interestingly, another class of covalent binding $\mathrm{Hb}$ allosteric modifiers was discovered having a symmetric structure mediated by a disulfide link $[47,51]$. Those modifiers were identified after a random biological screening of 38 , 700 compounds using small molecule microarrays, followed by a high-throughput assay to test the selected molecules that modified $\mathrm{Hb}$ affinity for oxygen. TD-1(di(5-(2,3-dihydro-1,4-benzodioxin-2-yl)-4H-1,2,4-triazol-3-yl)disulfide) was the capstone of the evaluated compounds where it showed a greater effect even than 5-HMF, on oxygen affinity of human hemoglobin.<smiles>c1ccc2c(c1)OCC(c1nnc(SSc3nnc(C4COc5ccccc5O4)[nH]3)[nH]1)O2</smiles>

TD-1

The X-ray crystallographic analysis of Hb-TD-1 complex indicated that a monomer of the TD-1 structure reacts covalently to both $\beta$-Cys93 and $\beta$-Cys112. Indeed, it was found also that TD-1 reacts in a monomeric pattern, but non-covalently to the central water cavity of the $\mathrm{Hb}$ tetramer, stabilizing the relaxed (R) state, and disturbing the salt-bridge interaction between $\beta$-His146 and $\beta$-Asp94, destabilizing the tens (T) stat. TD-1, was also reported to prevent sickling of human sickle cells. Encouraged by these results, another triazole disulfide, TD-3, was published by the same researcher group, to bind covalently to the $\mathrm{Hb}$ as TD-1 does but has no superior effect than the later as a hemoglobin modifier [46].<smiles>c1[nH]nnc1SSc1c[nH]nn1</smiles>

TD-3

\subsection{Conclusion}

Hundreds of covalent binding hemoglobin allosteric modifiers that successfully increase $\mathrm{HbS}$ oxygen affinity and decrease its polymerization were published. Many of these modifiers have reached human clinical trials, but unfortunately none has been introduced to the market yet. This could be attributed to the fact that hemoglobin is a large molecule having different target sites, which requires highly potent therapeutic agent (nanomolar affinity). In addition, these drugs should be safe and possess suitable oral pharmacokinetic and pharmacodynamic properties. Such ideal drug candidate needs more efforts to be identified and developed.

\section{Abbreviations}

5-HMF: 5-Hydroxymethyl-2-furfural; DPG: 2,3-Diphosphoglycerate; ECA: Ethacrynic acid; HAM: Hemoglobin allosteric modifiers; Hb: Hemoglobin; HbA: Normal hemoglobin molecule; HbS: Sickled hemoglobin; RBC: Red blood corpuscles; SCD: Sickle cell disease

\section{Acknowledgements}

Not applicable.

\section{Authors' contributions}

EA and MT were responsible for collecting data, summarized it, and helped in revising the written manuscript. MM was responsible for writing the manuscript, format its design, arrange its ideas, and prepare it for publication. All authors read and approved the final manuscript.

Funding

Not applicable.

Availability of data and materials

All information in the manuscript is referred in the included references.

Ethics approval and consent to participate Not applicable.

\section{Consent for publication \\ Not applicable.}

\section{Competing interests}

The authors declare that they have no competing interests

Received: 5 July 2019 Accepted: 9 October 2019

Published online: 21 December 2019

\section{References}

1. Abdulmalik O, Ghatge MS, Musayev FN, Parikh A, Chen Q, Yang J, Nnamani I. Danso-Danquah R, Eseonu DN, Asakura T, Abraham DJ (2011)

Crystallographic analysis of human hemoglobin elucidates the structural basis of the potent and dual antisickling activity of pyridyl derivatives of vanillin. Acta Crystallogr D Biol Crystallogr 67(11):920-928 
2. Abdulmalik O, Safo MK, Chen Q, Yang J, Brugnara C, Ohene-Frempong K, Abraham DJ, Asakura T (2005) 5-Hydroxymethyl-2-furfural modifies intracellular sickle haemoglobin and inhibits sickling of red blood cells. Br J Haematol 128(4):552-561

3. Abraham DJ, Mehanna AS, Wireko FC, Whitney J, Thomas RP, Orringer EP (1991) Vanillin, a potential agent for the treatment of sickle cell anemia. Blood. 77(6):1334-1341

4. Abraham EC, Stallings M, Abraham A, Garbutt GJ (1982) Modification of sickle hemoglobin by acetaldehyde and its effect on oxygenation, gelation and sickling. Biochim Biophys Acta 705(1):76-81

5. Aruoma Ol (1992) Dietary management of sickle cell anaemia with vanillin. Free radical research communications. Free Radic Res Commun 17(5):349-350

6. Batchvarova M, Shan S, Zennadi R, Lindgren M, Leitgeb A, Tamsen PS (2013) Sevuparin reduces adhesion of both sickle red cells and leukocytes to endothelial cells in vitro and inhibits vaso-occlusion in vivo. Blood. 122(21):182-182

7. Beddell CR, Goodford PJ, Kneen G, White RD, Wilkinson S, Wootton R (1984) Substituted benzaldehydes designed to increase the oxygen affinity of human haemoglobin and inhibit the sickling of sickle erythrocytes. $\mathrm{Br} J$ Pharmacol 82(2):397-407

8. Beddell CR, Kneen G, White RD (1979) The anti-sickling activity of a series of aromatic aldehydes [proceedings]. Br J Pharmacol 66(1):70

9. Benesch RE, Kwong S, Hudson BB, Krumdieck CL (1988) pAminobenzoylpolyglutamates with hydrophobic end groups. A new class of inhibitors of hemoglobin S polymerization. J Biol Chem 263(1):69-71

10. Brugnara C, de Franceschi L, Alper SL (1993) Inhibition of $\mathrm{Ca}^{2+}$-dependent $\mathrm{K}^{+}$transport in sickle cell erythrocytes by clotrimazole and other imidazole derivatives. J Clin Invest 92:520-526

11. Cerami A, Manning JM (1971) Potassium cyanate as an inhibitor of the sickling of erythrocytes in vitro. Proc Natl Acad Sci 68(6):1180-1183

12. Chang H, Ewert SM, Bookchin RM, Nagel RL (1983) Comparative evaluation of fifteen anti-sickling agents. Blood. 61(4):693-704

13. Chang J, Patton JT, Sarkar A, Ernst B, Magnani JL, Frenette PS (2010) GMI1070, a novel pan-selectin antagonist, reverses acute vascular occlusions in sickle cell mice. Blood. 116(10):1779-1786

14. Charache S, Terrin ML, Moore RD, Dover GJ, Barton FB, Eckert SV, McMahon $\mathrm{RP}$, Bonds DR, Investigators of the multicenter study of hydroxyurea in sickle cell anemia (1995) Effect of hydroxyurea on the frequency of painful crises in sickle cell anemia. N Engl J Med 332(20):1317-1322

15. Cheung AT, Chan MS, Ramanujam S, Rangaswami A, Curl K, Franklin P, Wun T (2004) Effects of poloxamer 188 treatment on sickle cell vasoocclusive crisis: computer-assisted intravital microscopy study. J Investig Med 52(6):402-406

16. dos Santos JL, Chin CM (2011) Recent insights on the medicinal chemistry of sickle cell disease. Curr Med Chem 18(15):2339-2358

17. Dykes G, Crepeau RH, Edelstein SJ (1978) Three-dimensional reconstruction of the fibres of sickle cell haemoglobin. Nature. 272(5653):506-510

18. Dykes GW, Crepeau RH, Edelstein SJ (1979) Three-dimensional reconstruction of the 14-filament fibers of hemoglobin S. J Mol Biol 130(4):451-472

19. Farthing D, Sica D, Abernathy C, Fakhry I, Roberts JD, Abraham DJ, Swerdlow P (1999) High-performance liquid chromatographic method for determination of vanillin and vanillic acid in human plasma, red blood cells and urine. J Chromatogr B Biomed Sci Appl 726(1-2):303-307

20. Fatope MO, Abraham DJ (1987) Design, synthesis, and testing of potentia antisickling agents. 10. 2, 2-Dimethylchroman-6-ylalkanoic acids. J Med Chem 30(11):1973-1977

21. Ferreira de Melo TR, Chin CM, dos Santos JL (2014) What are the most promising emerging therapies for sickle cell disease? Future Med Chem 6(9):979-982

22. Field JJ, Lin G, Okam MM, Majerus E, Keefer J, Onyekwere O, Ross A, Campigotto F, Neuberg D, Linden J, Nathan DG (2013) Sickle cell vasoocclusion causes activation of iNKT cells that is decreased by the adenosine A2A receptor agonist regadenoson. Blood. 121(17):3329-3334

23. Fung LW, Ho C, Roth EF, Nagel RL (1975) The alkylation of hemoglobin S by nitrogen mustard. High resolution proton nuclear magnetic resonance studies. J Biol Chem 250(12):4786-4789

24. Gardos $G$ (1958) The function of calcium in the potassium permeability of human erythrocytes. Biochim Biophys Acta 30(3):653-654

25. Gorecki M, Rich A (1977) Sickle hemoglobin aggregation: a new class of inhibitors. Science 196(4295):1216-1219
26. Grygorczyk R, Schwarz W, Passow H (1984) Ca2+-activated K+ channels in human red cells. Comparison of single-channel currents with ion fluxes. Biophys J 45(4):693-698

27. Hahn EV, Gillespie EB (1927) Sickle cell anemia: report of a case greatly improved by splenectomy. Experimental study of sickle cell formation. Arch Intern Med 39(2):233-254

28. Hannemann A, Cytlak UMC, Gbotosho OT, Rees DC, Tewari S, Gibson JS (2014) Effects of o-vanillin on K+ transport of red blood cells from patients with sickle cell disease. Blood Cell Mol Dis 53(1-2):21-26

29. Harris JW (1950) Studies on the destruction of red blood cells. VIII. Molecular orientation in sickle cell hemoglobin solutions. Proc Soc Exp Biol Med 75(1):197-201

30. Herrick JB (1910) Peculiar elongated and sickle-shaped red blood corpuscles in a case of severe anemia. Arch Intern Med 6:517-521

31. Hsiao CH, Li W, Lou TF, Baliga BS, Pace BS (2006) Fetal hemoglobin induction by histone deacetylase inhibitors involves generation of reactive oxygen species. Exp Hematol 34(3):264-273

32. Ilesanmi OO (2010) Pathological basis of symptoms and crises in sickle cell disorder: implications for counseling and psychotherapy. Hematol Rep 2(1):e2

33. Ingram VM (1956) A specific chemical difference between the globins of normal human and sickle-cell anaemia haemoglobin. Nature. 178(4537):792-794

34. Ingram VM (1957) Gene mutations in human haemoglobin: the chemical difference between normal and sickle cell haemoglobin. Nature. 180(4581):326-328

35. Ishii TM, Silvia C, Hirschberg B, Bond CT, Adelman JP, Maylie J (1997) A human intermediate conductance calcium-activated potassium channel. Proc Natl Acad Sci 94(21):11651-11656

36. Jenner PM, Hagan EC, Taylor JM, Cook EL, Fitzhugh OG (1964) Food flavourings and compounds of related structure I. Acute oral toxicity. Food Cosmet Toxicol 2:327-343

37. Johnson RM, Feo CJ, Nossal M, Dobo I (1985) Evaluation of covalent antisickling compounds by PO2 scan ektacytometry. Blood. 66(2):432-438

38. Kennedy PE, Williams FL, Abraham DJ (1984) Design, synthesis, and testing of potential antisickling agents. 3. Ethacrynic acid. J Med Chem 27(2):103-105

39. Kubota S, Yang JT (1977) Oligopeptides as potential antiaggregation agents for deoxyhemoglobin S. Proc Natl Acad Sci 74(12):5431-5434

40. Magbubah Essack M, Bajic V, Radovanovic A (1989) Treatment of sickle cell disease. U.S. Patent $9655905 B 2$

41. Mandarino D, Kawar Z, Alvarez R, Falconer D, Rollins SA, Rother RP (2013) Placebo-controlled, double-blind, first-in-human, ascending single dose and multiple dose, healthy subject study of intravenous-administered SelG1, a humanized anti-P-selectin antibody in development for sickle cell disease. Blood 122(21):970-970

42. Marotta CA, Wilson JT, Forget BG, Weissman SM (1977) Human beta-globin messenger RNA. III. Nucleotide sequences derived from complementary DNA. J Biol Chem 252(14):5040-5053

43. May A, Bellingham AJ, Huehns ER, Beaven GH (1972) Effect of cyanate on sickling. Lancet 299(7752):658-661

44. Metcalf B, Chuang C, Dufu K, Patel MP, Silva-Garcia A, Johnson C, Lu Q, Partridge JR, Patskovska L, Patskovsky Y, Almo SC (2017) Discovery of GBT440, an orally bioavailable R-state stabilizer of sickle cell hemoglobin. ACS Med Chem Lett 8(3):321-326

45. Molokie R, Lavelle D, Gowhari M, Pacini M, Krauz L, Hassan J, Ibanez V, Ruiz MA, Ng KP, Woost P, Radivoyevitch T (2017) Oral tetrahydrouridine and decitabine for non-cytotoxic epigenetic gene regulation in sickle cell disease: a randomized phase 1 study. PLoS Med 14(9):e1002382

46. Nakagawa A, Ferrari M, Schleifer G, Cooper MK, Liu C, Yu B, Berra L, Klings ES, Safo RS, Chen Q, Musayev FN (2018) A triazole disulfide compound increases the affinity of hemoglobin for oxygen and reduces the sickling of human sickle cells. Mol Pharm 15(5):1954-1963

47. Nakagawa A, Lui FE, Wassaf D, Yefidoff-Freedman R, Casalena D, Palmer MA, Meadows J, Mozzarelli A, Ronda L, Abdulmalik O, Bloch KD (2014) Identification of a small molecule that increases hemoglobin oxygen affinity and reduces SS erythrocyte sickling. ACS Chem Biol 9(10):2318-2325

48. Nigen AM, Manning JM (1977) Inhibition of erythrocyte sickling in vitro by DL-glyceraldehyde. Proc Natl Acad Sci 74(1):367-371

49. Nigen AM, Njikam N, Lee CK, Manning JM (1974) Studies on the mechanism of action of cyanate in sickle cell disease oxygen affinity and gelling properties of hemoglobin S carbamylated on specific chains. J Biol Chem 249(20):6611-6616 
50. Nnamani IN, Joshi GS, Danso-Danquah R, Abdulmalik O, Asakura T, Abraham DJ, Safo MK (2008) Pyridyl derivatives of benzaldehyde as potential antisickling agents. Chem Biodivers 5(9):1762-1769

51. Oder E, Safo MK, Abdulmalik O, Kato GJ (2016) New developments in antisickling agents: can drugs directly prevent the polymerization of sickle haemoglobin in vivo? Br J Haematol 175(1):24-30

52. Oksenberg D, Dufu K, Patel MP, Chuang C, Li Z, Xu Q, Silva-Garcia A, Zhou C, Hutchaleelaha A, Patskovska L, Patskovsky Y (2016) GBT 440 increases haemoglobin oxygen affinity, reduces sickling and prolongs RBC half-life in a murine model of sickle cell disease. Br J Haematol 175(1):141-153

53. Omar A, Mahran M, Ghatge M, Bamane F, Ahmed M, El-Araby M, Abdulmalik O, Safo M (2016) Aryloxyalkanoic acids as non-covalent modifiers of the allosteric properties of hemoglobin. Molecules. 21(8):1057

54. Omar AM, Mahran MA, Ghatge MS, Chowdhury N, Bamane FHA, El-Araby ME, Abdulmalik O, Safo MK (2015) Identification of a novel class of covalent modifiers of hemoglobin as potential antisickling agents. Org Biomol Chem 13(22):6353-6370

55. Pauling L, Itano HA, Singer SJ, Wells IC (1949) Sickle cell anemia, a molecular disease. Science. 110(2865):543-548

56. Perutz MF, Fermi G, Abraham DJ, Poyart C, Bursaux E (1986) Hemoglobin as a receptor of drugs and peptides: $X$-ray studies of the stereochemistry of binding. J Am Chem Soc 108(5):1064-1078

57. Rees DC, Williams TN, Gladwin MT (2010) Sickle-cell disease. Lancet 376(9757):2018-2031

58. Roth EF, Nagel RL, Bookchin RM, Grayzel AJ (1972) Nitrogen mustard: an "in vitro" inhibitor of erythrocyte sickling. Biochem Biophys Res Commun 48:612-618

59. Russu IM, Lin AK, Yang CP, Ho C (1986) Molecular basis for the antisickling activity of aromatic amino acids and related compounds: a proton nuclear magnetic resonance investigation. Biochemistry. 25(4):808-815

60. Safo MK, Abdulmalik O, Danso-Danquah R, Burnett JC, Nokuri S, Joshi GS, Musayev FN, Asakura T, Abraham DJ (2004) Structural basis for the potent antisickling effect of a novel class of five-membered heterocyclic aldehydic compounds. J Med Chem 47(19):4665-4676

61. Safo, M.K., Danso-Danquah, R., Nokuri, S., Musayev, F.N., Joshi, G.S., Burnett, J. C. and Abraham, D.J., Xechem International Inc, 2007. Anti-sickling agents. US Patent 7,160,910

62. Safo MK, Kato GJ (2014) Therapeutic strategies to alter the oxygen affinity of sickle hemoglobin. Hematology/Oncology Clinics. 28(2):217-231

63. Saunthararajah Y, Lavelle D, DeSimone J (2004) DNA hypo-methylating agents and sickle cell disease. Br J Haematol 126(5):629-636

64. Strand LP, Scheline RR (1975) The metabolism of vanillin and isovanillin in the rat. Xenobiotica. 5(1):49-63

65. Taliaferro WH, Huck JG (1923) The inheritance of sickle-cell anaemia in man. Genetics 8(6):594-598

66. Telen MJ (2016) Beyond hydroxyurea: new and old drugs in the pipeline for sickle cell disease. Blood. 127(7):810-819

67. Walder JA, Walder RY, Arnone A (1980) Development of antisickling compounds that chemically modify hemoglobin $\mathrm{S}$ specifically within the 2 , 3-diphosphoglycerate binding site. J Mol Biol 141(2):195-216

68. Walder JA, Zaugg RH, Walder RY, Steele JM, Klotz IM (1979) Diaspirins that crosslink. Beta. Chains of hemoglobin: bis (3, 5-dibromosalicyl) succinate and bis (3, 5-dibromosalicyl) fumarate. Biochemistry. 18(20):4265-4270

69. Wishner BC, Ward KB, Lattman EE, Love WE (1975) Crystal structure of sicklecell deoxyhemoglobin at $5 \AA$ resolution. J Mol Biol 98(1):179-194

70. Zaugg RH, Walder JT, Klotz IM (1977) Schiff base adducts of hemoglobin. Modifications that inhibit erythrocyte sickling. J Biol Chem 252(23):8542-8548

71. Zhang C, Li X, Lian L, Chen Q, Abdulmalik O, Vassilev V, Lai CS, Asakura T (2004) Anti-sickling effect of MX-1520, a prodrug of vanillin: an in vivo study using rodents. Br J Haematol 125(6):788-795

\section{Publisher's Note}

Springer Nature remains neutral with regard to jurisdictional claims in published maps and institutional affiliations.

\section{Submit your manuscript to a SpringerOpen ${ }^{\circ}$ journal and benefit from:}

- Convenient online submission

- Rigorous peer review

- Open access: articles freely available online

- High visibility within the field

- Retaining the copyright to your article

Submit your next manuscript at $\boldsymbol{\nabla}$ springeropen.com 